\title{
Forest Management Plans in Los Planes de La Palma, El Salvador
}

\author{
Gisselle A. Mejia, Blair Orr* \\ School of Forest Resources and Environmental Science, Michigan Technological University, Houghton, MI, USA \\ Email: mejia.gisselle@gmail.com, "bdorr@mtu.edu
}

Received 14 October 2015; accepted 13 November 2015; published 16 November 2015

Copyright (C) 2015 by authors and Scientific Research Publishing Inc.

This work is licensed under the Creative Commons Attribution International License (CC BY). http://creativecommons.org/licenses/by/4.0/

(c) (i) Open Access

\begin{abstract}
Fourteen farmers with small woodlots were interviewed about the forest management plans promoted by the government of El Salvador. As expected, farmers managed for many utilitarian products such as firewood and timber, but the farmers also expressed a strong set of environmental concerns revolved around the ecological value of their woodlots. Farmers generally approved of forest management plans as they saw how plans contributed to sustainable forestry on their woodlots. Farmers had concerns about specific silvicultural practices and about transportation of harvested timber.
\end{abstract}

\section{Keywords}

Woodlots, Ecotourism, Forest Law, Chalatenango, Sustainable Management

\section{Introduction}

Los Planes de La Palma (Los Planes) was located in the highlands of the northern Municipality of Chalatenango, which was heavily affected by deforestation during El Salvador's Civil War (1980-1992). The national military bombed and torched woodlots to drive out revolutionary rebels who sought refuge in the country's forests [1]. The lack of law enforcement further enabled the exploitation of forests through illegal commercial timber sales [2]. Remaining forest cover was mostly found in shade-grown coffee plantations [3]. The Federal Forest Law was instituted on February 8, 1973 to address the problems affecting forest resources in El Salvador. However, the lack of regulatory enforcement rendered it ineffective. In 2002, the law was revised to include more incentives for woodlot owners and eliminated the sanctions that were seen as obstacles to sustainable woodlot management. The law did not regulate private shade-grown coffee plantations because this type of forest cover was under a different land use category.

${ }^{*}$ Corresponding author. 
From 2001 to 2007, Proyecto de Desarollo Sostenible en Zonas de Fragilidad Ecólogica en la Región del Trifinio (PRODERT) was launched by the government to promote small-business development and income diversity among rural people in El Salvador by supporting income-generating projects. In an effort to promote sustainable forest management, the Ministerio de Agricultura y Ganaderia (Ministry of Agriculture and Livestock) (MAG) administered the program by providing technical trainings, technical assistance, and best practices to woodlot owners in the area of Los Planes and its surrounding communities [4]. PRODERT technicians worked with woodlot owners to develop a 5-year forest management plan for each woodlot. The forest management plans provided woodlot owners with silvicultural activities to implement over 5 years and allowed them to sustainably harvest timber for commercial sale.

This paper examines the perceptions of small farmers of the plan and the impacts the plans have had on how farmers manage woodlots. We hypothesize that woodlot owners will primarily focus on utilitarian values of their woodlots, will appreciate technical support but will not necessarily appreciate the associated bureaucratic problems. We frame the discussions with farmers around three key areas: the motivation of farmers, the constraints and benefits that farmers see as associated with management plans and the value of management plans as learning tools for woodlot operations.

\section{Experimental Methods}

\subsection{Study Area}

The Municipality of Chalatenango, located in La Zona Alta (the Highlands) of El Salvador, contains one the last remaining forests; currently only $2.5 \%$ of the country remains forested [5]. The forest is classified as humid lower montane and is composed of mixed pine (Pinus spp.) and mixed pine-oak (Quercus spp.). Common species include Pinus oocarpa, Pinus maximinoi, Pinus pseudostrobus, Pinus rudis, and cypress (Cupressus spp.), and to a lesser degree, liquidambar (Liquidambar styraciflua) [6]. The hills that surround the village of Los Planes reach an elevation of 1700 - 1800 masl with slopes up to $31 \%$ - 60\% [6]. The region is cooler than much of El Salvador, with an annual mean temperature of $22^{\circ} \mathrm{C}$ and an annual mean precipitation of $2300 \mathrm{~mm}$. The sandy clay loam soil, the most common soil texture class, is suitable for agriculture, but hillside farming leaves the soil susceptible to erosion [6]-[8]. Although water can be limited during the dry season (November-May), the nearby Sumpul and Chiquito Rivers supply fresh water to the region [6].

\subsection{Data Collection}

The data collection for this research project included a total of 14 extended interviews with woodlot owners: 10 with forest management plans and four woodlot owners without. The research procedures were approved by the Michigan Technological University Institutional Review Board. The small sample size and the longer, informal interviews allowed for the collection of detailed qualitative information, while the opened-ended questions allowed for the discovery of new information not initially hypothesized. This also strengthened the research by giving participants the opportunity to converse freely with the interviewer [9] [10]. The unstructured and semistructured interviews were recorded and critical segments were transcribed. A questionnaire was developed to identify woodlot owners' attitudes, beliefs, and values regarding forest management, and to identify how they apply and follow the requirements in forest management plan. Additionally, a technical field survey allowed for more interaction with woodlot owners, and direct observation led to noting practices and techniques used by woodlot owners, such as logging and weeding operations [11]. While the field surveys collected useful information about each woodlot, the relaxed atmosphere allowed easy give-and-take discussions between the first author and the farmers. Field data collected from each woodlot included woodlot size, dominant species, basal area, diameter breast height (DBH), regeneration plots, distance to the owners' homes, percent of ground cover type, coarse woody debris, aspect, and topography [12] [13].

\section{Results and Discussion}

The objective of this study was to determine the impact of forest management plans on woodlot owners and how those owners perceived forest management plans. The discussions with farmers were open-ended but centered on the following three areas of inquiry: 
What are farmers' motivations for owning and managing woodlots?

What are the constraints (disadvantages) and benefits (advantages) of the forest management plan?

What have farmers learned through the forest management plans, do farmers apply all of the techniques

learned under the forest management plan and, if so, how?

\subsection{What Are Farmers' Motivations for Owning and Managing Woodlots?}

As expected, utilitarian values were important to farmers. Timber harvesting was a key goal. Maintaining and owning a woodlot provides supplemental income which farmers can use to reinvest in their woodlots or enhance their farm fields. Additionally, woodlots provide resources useful for medicinal purposes, firewood, and water.

Traditionally, farmers pass on their land to descendants and woodlots are valued, maintained and preserved for future generations. One farmer explained, "I'm planting and taking care of the trees not for me, but for the future... I'm not going to be alive when those trees are big enough to harvest. That job will be for my grandchildren”. Farmers see woodlots as a resource that will sustain the lives of their children, providing the same benefits to their children as the farmers currently receive. Without explicitly stating so, they view the woodlot as sustainable through generations.

Land inheritance can present problems. Land subdivision can impact farmers' enrollment in a forest management plan because the minimum land requirement for program participation is 6.9 ha. In one case, a farmer enrolled his woodlot by incorporating his son's adjacent woodlot into his forest management plan.

Woodlots are attractive to affluent prospective buyers looking to build homes in the woods. The sale of woodlots provides farmers with additional income in times of need. However, only two of the farmers interviewed, both of whom had debt with the bank for land previously purchased, expressed interest in selling their woodlots. Generally, farmers wanted to maintain their ownership.

Most farmers own several parcels of land which they dedicate to various uses including crop cultivation, pasture or grassland. With basic agricultural needs met on these parcels, farmers can maintain woodlots for household resource diversity. While cleared land is preferred for farming or pasture, accessibility, topography and proximity to a water source are also factors that farmers consider when allocating land to different purposes. Woodlots are often located on land less suited to farming. Farmers realize a diverse landscape can provide a diverse and more resilient resource base for their households.

The highlands of El Salvador are a destination for Salvadorans and tourists interested in hiking and climbing the country's highest the peak, "El Pital", on the border of Honduras. As a result, ecotourism has been an attractive industry among woodlot owners with property along streams. One woodlot owner with a management plan dedicated part of his 3.2 ha parcel for recreational space for visitors interested in hiking and camping, and has further invested in enhancing natural space by planting more trees and plants. Two woodlot owners with management plans were considering the idea of diversifying land use. "I want to fix the area, especially around the river, so people can come spend afternoons here. I am thinking of planting more trees, taking the cows out of there, making it all nice and pretty". While this may still be considered a utilitarian motivation as the net result is the economic benefits of ecological restoration, it is shows a shift towards less utilitarian, harvest-focused use of the woodlot. This ecological consciousness was not a landowner motivation that was anticipated when the study was designed.

\subsection{What Are the Constraints (Disadvantages) and Benefits (Advantages) of the Forest Management Plan?}

\subsubsection{Constraints}

At the start of the program, woodlot owners felt that the costs of developing forest management plans made them unaffordable. The government of El Salvador initially provided incentives that made a forest management plan an affordable option for a woodlot owner. Eventually the value of a plan became evident; most woodlot owners with a current management plan expressed interest in renewing it at their own cost. Some farmers indicated skepticism of the management plan based on the belief that sustainably managing a woodlot takes a conscious effort while some people may be driven by the financial motives. As one farmer phrased the dilemma, "Many times we see the necessities of today, we don't see the necessities of tomorrow".

While most farmers with forest management plans complied with the technical requirements under the management plan, firebreaks and weeding were perceived as tedious and time consuming. These activities are costly 
and labor-intensive tasks and completing them required hired help. During the winter season, weeds grow more quickly and become widespread throughout the woodlot, requiring frequent maintenance to enable regeneration of desired species. Woodlots that were not cared for showed evidence of the neglect, with overgrown weeds dominating the understory. Farmers felt that the plans did not consider the complete context of smallholder farming.

Farmers often stated that law enforcement was a deterrent to woodlot management. The environmental police, a branch of the police force, are tasked with the responsibility of enforcement and compliance of the forest management plan. Therefore, forest management plan violations are regulated by the police and are enforced through penalties and summons. Farmers felt that the environmental police tend to abuse their power by unfairly punishing woodlot owners who are conducting legal operations on their property. Several farmers claimed to have experienced instances where police confiscated logging equipment, such as chainsaws, despite their or their workers' possession of legal documentation permitting logging operations. When confiscation occurs, farmers have to undergo costly and bureaucratic processes to have their equipment returned.

Transportation permits that allow owners to move harvested wood are a two-edged sword. Farmers with woodlot management plans are issued preapproved permits as part of their forest management plan, bypassing the approval process administered by the forest technician. Two woodlots owners expressed concern regarding the transportation permits issued to people who are transporting timber outside the community. One woodlot owner reported, “There are a lot of people that sell wood here and do not have management plans”. Transportation permits are issued by the forestry office for a small fee regardless of woodlot ownership or possession of a forest management plan. The purpose of the transportation permit is to prevent illegal logging operations by regulating the volume of timber transported within the country. However, some farmers sell or give away their transportation permits to others who illegally harvest timber either on their own or someone else's property. Speaking about a community member who does not own a woodlot, a farmer said, "She sold two trucks full of wood with someone else's transportation permit, she said someone sold it to her".

There are some misunderstandings amongst woodlots owners with forest management plans surrounding the tree selection process applied by technicians. According to the forest technicians, they select trees based on the total volume of harvestable wood per hectare. The volume in each woodlot is calculated using measurement guidelines which have been developed by the Honduran Forest Service. Seven out of ten woodlot owners with forest management plans were dissatisfied with the trees selected by technicians for harvesting, claiming technicians often choose lesser quality or undesirable trees. One woodlot owner stated that the forest technician often selected trees that were damaged or too small to sell for profit. However, a closer look at the woodlot and forest management plan for this owner showed that the woodlot was under-stocked. Another woodlot owner said, "I would like to cut the bigger trees, but they do not mark those, they mark the most deformed and ugly one with a bunch of branches. That's the one the forest technician marks, not the prettiest one”.

Again, woodlot owners are ambivalent about technicians and timber marking. While it is possible that woodlot owners may not understand the forest management plan, most woodlot owners generally supported the plan’s strict guidelines and policies. One woodlot owner explained, "Without laws there would be no (forest technician). Without regulations the people would cut everything, there would be no trees left”. On the other hand, a common misunderstanding by people in the community is that forest management plans give woodlot owners complete freedom to exploit their woodlots. As a result some woodlot owners have had their forest management plans terminated due to negligent management or illegal logging. The misunderstandings and misconceptions about the forest management plan may be a reflection of inadequate education and training.

\subsubsection{Benefits (Advantages)}

There is a general understanding among woodlot owners interviewed that sustainable woodlot management is the best way to guarantee that they can continue long-term use of natural resources. One woodlot owner explained that the restrictions under the forest management plan encourages woodlot owners to conserve their forest resources for future use; "Right now I do not want to cut anymore trees, I want them to keep growing so in five years I have (trees to cut) again”. Despite the small size of his woodlot he was able to gain the benefits associated with a forest management plan.

Most woodlot owners agreed that the forest management plans meet their needs and are appropriate for their management objectives. A consulting forester explained that due to the small size of woodlots in El Salvador, management plans are designed using two simple computer programs; Microsoft Excel is used to analyze field 
data and MapMaker, a free online program, to create the maps. Most farmers felt that the forest management plan provided them with the flexibility to manage their property as needed and that the rules and requirements were appropriate. In 2002, an amendment to the forestry law provided woodlot owners with more incentives to generate income from and reinvest in their land, therefore enabling the application of sustainable practices. One woodlot owner explained that, "With the forest management plan... I could invest from my own pockets to maintain and provide proper care of the woodlots and utilize the resources in the woodlot. The forest management plan has made all that possible, while improving the woodlot”.

The forest management plan generates employment in the community. Logging is a labor-intensive and specialized operation that requires workers. One logger in the community owns chainsaws and a portable sawmill to cut wood to specified dimensions. Eight out of ten woodlot owners said they contract with this logger when they harvest on their property. Unskilled manual labor is usually conducted by workers hired either from outside or inside the community who are paid $\$ 5$ to $\$ 7$ per day.

Woodlot owners with management plans are provided with information on how to safely and properly conduct logging as part of their training. "The PRODERT technicians who were helping us take out the forest management plan brought videos and we watched them in (a) big screen. This was so we could have an idea of how to log trees. If I throw (the tree) one way and there are a lot of young trees in that side, then I cannot throw it on top of them. I have to (climb) the tree and prune it, then throw it to the side where there are no trees”. However, workers are not required by law to have formal training or certification to properly conduct logging operations. Therefore, owners often have to closely monitor the work conducted or train the workers to ensure that logging is being conducted safely and properly.

Woodlot owners see replanting requirements as a benefit. Replanting is one of the forest management plan's requirements; however, neither MAG nor the regional forest service provides woodlot owners with seedlings. Many woodlot owners acquire tree seedlings through agricultural programs. PRODERT or Programa Ambiental de El Salvador (PAES) supply fruit tree and pine seedlings to farmers at no cost to promote income generation, increase forest cover, and reduce soil erosion in the community. Some woodlot owners claim the seedlings provided by agricultural programs are of low quality, making them more susceptible to deformities or premature death. A woodlot owner given trees through the PAES program recounted. "This week I planted around 150 trees in the whole area I have been working in the woodlot. Some I had already planted and they already died". Although no one single reason was identified as a contributing factor, several factors may be interfering with the survival of trees: cattle eat the seedlings, improper planting, plant competition, and poor quality seedlings.

One farmer felt that natural regeneration is "stronger", better adapted to the local area and more likely to reach maturity than planted seedlings. This was confirmed by the field survey, which found natural regeneration of pine present in all woodlots. Natural regeneration of pines is also consistent with woodlots owners' interest in protecting pine trees, which are higher in value for both commercial and personal purposes. Oak regeneration was also present and preferred as firewood. Cypress seedlings were found planted in several woodlots, but natural regeneration of cypress was absent in all woodlots surveyed. Only one woodlot contained cypress as a co-dominant species, which the owner explained resulted from maintaining the trees planted along the boundaries of the property. The field survey showed the cypress was found only in sample plots along the property boundaries.

Slash from logging operations provides firewood for the woodlot owners. This is important for some landowners and less important for others. Trespassing is a common practice by people looking for firewood, but is not considered a major offense by all of the woodlot owners. Most people collect the slash left from logging without harming valuable timber. One woodlot owner said, "It is not a big problem. A lot of people take the slash away. One takes away what one needs and then there are people that have needs. As long as they do not take the standing trees, or if it is another type of tree they want to take”. Only in one woodlot, where logging had recently occurred, was coarse woody debris was found in all plots. The woodlot owner explained he had attempted to discourage trespassing after repeated thefts of slash that had been cut and stacked for firewood.

The on-the-ground flexibility of the forest technicians was appreciated by woodlot owners. For example, minimum woodlot size was a requirement for an approved forest management plan. The average woodlot size among woodlot owners in Los Planes is smaller than the standard required by PRODERT. Technicians still approved plans as all parties agreed that a well-managed woodlot with a plan as a desirable outcome.

Another common land use for woodlots is pasture, although the practice is in violation of the forest management plan and officially discouraged by the forest technicians. Some grazing does occur. Most woodlot owners 
do not own cattle, but the few who do explained that cattle do not eat pine or cypress trees-two of the species regarded with the most economic value. One of the benefits of the forest management plan is that it recognizes the integrated practice of land management by allowing the continued use of land designated for agriculture. This enables woodlot owners to maintain areas of their property for agricultural purposes, while encouraging sustainable management of woodlots. The freedom to properly manage their natural resources motivates woodlot owners to protect and conserve their resources.

\subsection{What Have Farmers Learned through the Forest Management Plans, Do Farmers Apply All the Techniques Learned under the Forest Management Plan, and If So, How?}

\subsubsection{Woodlot Management Techniques}

The forest management plan's basic requirements for proper woodlot maintenance are weeding, planting, thinning, and pruning. Pruning and thinning, while required, are harder and less likely to be implemented because it takes time, hired labor, and money. Hired laborers are the same people who work in farm fields. Woodlot owners reminisce of a time when these practices were not necessary because woodlots were dense and natural regeneration was abundant, but most woodlot owners recognize that these practices are necessary for sustainable management today. The forest management plan serves as a guideline for woodlot owners to implement techniques for sustainable management over five years, giving woodlot owners the responsibility of managing their own woodlots. One woodlot owner explained, "The forest management plan is based on what the forest technician indicates. For example, trees can be harvested and trees cannot be harvested. So, there is a harvesting plan that the forest technician decides in accordance with what has been harvested (before), what is remaining and the regeneration occurring in the woodlot. (Regeneration) can be planted or natural. And to protect them for the future".

Only three woodlot owners expressed some disagreement about the techniques and practices required by the forest management plan, but generally agreed that the forest management plan allowed them to sustainably utilize their forest resources. Disagreement with certain forest management requirements is the result of introducing new practices that are different from the way woodlot owners traditionally managed their woodlots. One woodlot owner explained that, "When you read the forest management plan you know what you need to do and what you cannot do. I am not going to say that one does everything verbatim as written in the forest management plan, because one has ones weaknesses. And maybe the consequences do not allow one to manage one's woodlot (how it is expected), but we are always working hard (to manage it)". Overall, woodlot owners acknowledge that the forest management plan encourages sustainable woodlot management, and proper management relies on the motivation and decisions made by individual woodlot owners.

\subsubsection{Farmers' Perceptions of Broader Ecological Values}

We had originally hypothesized that the utilitarian values of tangible forest products such as timber and firewood would be primary motivations for woodlot management and forest management plans. Woodlot owners' attitudes and motivations include managing forest resources based on ecological principles. Their experience managing woodlots sustainably has provided woodlot owners with an understanding and appreciation for the ecological value of forest resources. Community members have also adopted an ecological perspective to forest resource management and recognize the value of sustainable forest management as a benefit to the community. This has influenced the expansion of ecotourism and increased the value of forested land due to growing interest in property ownership by wealthy Salvadorans.

The forest management plan recommends silvicultural practices, influencing the way woodlot owners think about and value their forest resources and teaching them how best practices improve stand quality. Weeding, slash removal, protection of natural regeneration and tree planting are necessary to guarantee the future of forest resources. A woodlot owner observed both the techniques and material values described above and how those are linked to the ecological values.

"(The forest management plan) has two types of impacts, an economic one and an ecological one. Ecologically, protecting nature and forest life, it has a negative impact because people think 'darn it, they are cutting the forests'. The economic one is that every penny one gains from harvesting is invested in the woodlot. That is a major factor. The result of those impacts is going to be seen in eight or ten years. When those people who are now saying 'look at how much they are harming the forests, cutting the trees', they are 
going to see that in ten years that (the forest management plan) is having a good result and how quickly the forest grew".

The growing interest in ecotourism is another sign of the change that has occurred over time-woodlot owners have discovered the economic value that their woodlots possess because of their ecological properties. Wealthy Salvadorans purchase forest land to build second homes for seasonal and weekend use. Prospective buyers' interests are centered on aesthetics and environmental protection; timber harvesting is not of interest to them. One woodlot owner explained, "People are realizing that without the forest there is no life". All woodlot owners maintained that the war deeply devastated forest resources in the community and that they have since adopted sustainable practices to conserve forest resources. A woodlot owner stated, "I have the belief that without forests we will not survive, therefore, I try to take care of mine”.

\section{Conclusions}

While woodlot owners share challenges as they implement the forest management plans in their woodlots, overall they feel that the forest management plan has had a positive impact in the community. One woodlot owner explains that, "The best thing is a forest management plan. There is a thorough use of forest resources and this improves the woodlot." He also explains that, "I am more excited and motivated to conduct all the activities promoted by the forest management plan. Because I know now I am to have money and invest more. The kids are going to school and all I make from it pays for many things... the house".

With the limited remaining forest cover in El Salvador, the forest management plans seem to be a positive step forward in protection of small, privately held woodlots. Those woodlot owners prefer natural regeneration, have stated that they will be willing to pay for their next forest management plan, and understand the ecological value in addition to the material utilitarian value which suggests that longer term and sustainable woodlot management has gained a foothold in Los Planes.

\section{Acknowledgements}

We thank the people of Los Planes de La Palma for their kindness and support and especially the fourteen anonymous farmers who contributed their time and knowledge to this study.

\section{References}

[1] Leiken, R.S. and Rubin, B. (1987) The Central American Crisis Reader: The Essential Guide to the Most Controversial Foreign Policy Issue Today. Summit Books, New York.

[2] Gonzalo, J. (2008) Personal Communication. MAG (Ministerio de Agricultura y Ganaderia), La Palma, Chalatenango.

[3] BBC News (2009) Coffee “May Save” El Salvador Wildlife. http://news.bbc.co.uk/2/hi/americas/4513593.stm

[4] DGFCR General Directorate of Forestry, Watershed, and Irrigation Ordination. Direcćion General de Ordenación F orestal, Cuencas, y Riego. http://www.mag.gob.sv

[5] Hecht, S.B., Kandal, S., Gomez, I., Cuellar, N. and Rosa, H. (2006) Globalization, Forest Resurgence, and Environmental Politics in El Salvador. World Development, 2, 308-323. http://dx.doi.org/10.1016/j.worlddev.2005.09.005

[6] Aguilar, M. (2008) Personal Communication. MAG (Ministerio de Agricultura y Ganaderia), Santa Ana.

[7] (1951) Soil Survey Manual. United States Department of Agriculture, Washington DC.

[8] Gonzalez-Vega, C., Rodrigez-Meza, J., Southgate, D., Maldonado, J.H. and Jorge, H.M. (2004) Poverty, Structural Adjustment, and Land Use in El Salvador: Learning from Household Panel Data. American Journal of Agricultural Economics, 5, 1367-1383. http://dx.doi.org/10.1111/j.0002-9092.2004.00691.x

[9] Bliss, J.C. and Martin, J.A. (1989) Identifying NIPF Management Motivations with Qualitative Methods. Forest Science, 2, 601-622.

[10] Ingemarson, F., Linghagen, A. and Erikson, L. (2006) A Typology of Small-Scale Private Forest Owners in Sweden. Scandinavian Journal of Forest Research, 3, 249-259. http://dx.doi.org/10.1080/02827580600662256

[11] Bernard, H.R. (1995) Research Methods in Anthropology: Qualitative and Quantitative Approaches. Altamira Press, Walnut Creek.

[12] Husch, B., Miller C.I. and Beers, T.W. (1982) Forest Mensuration. John Wiley \& Sons, New York.

[13] Avery, T.E. and Burkhart, H.E. (1983) Forest Measurements. McGraw-Hill Publishing, New York. 